\title{
Understanding Farmers' Behaviors and Driving Factors Toward Phosphorus Security of Crop Farming in Chaohu Watershed, China
}

\author{
Huijun Wu ${ }^{1 *}$, Zhouman Huang ${ }^{2}$, Liangmin Gao ${ }^{1}$, Haoran Li', \\ Tao Yang ${ }^{1}$, Jinxiang Yang ${ }^{1}$, Xiaolong $\mathbf{~ L i}^{1}$ \\ ${ }^{1}$ School of Earth and Environment, Anhui University of Science and Technology, Huainan 232001, China \\ ${ }^{2}$ Shool of Life Science, Wu Chang University of Technology, Wuhan 430223, China
}

Received: 18 April 2020

Accepted: 18 August 2020

\begin{abstract}
Phosphorus (P) is not only an essential nutrient required for plant growth, but also a pollutant with eutrophication. This brings a significant challenge to farmers, the main executive agent of farming. The study develops a model to determine farmers' behaviors impacting P security of farming, and analyzes drivers of these behaviors. The results illustrate the farmers' behaviors including sowing method, application of compound fertilizer, application of phosphate fertilizer, harvesting method, application of seed, and disposal of livestock manure have greatly impacted the P security in the farming system, in turn. Concerning with the factors obviously driving these key behaviors, farmers' income, prices of goods, application skill, acceptance of skill training, mechanization level, and regulation of waste disposal, etc. are explored, which are classified into four categories: market and purchasing, personal characteristics, planting condition, and regulation. Thus, the study highlights the opportunities for managing P, including improving mechanization level, raising farmers' environmental awareness, increasing efficiency of fertilizer application, optimizing planting condition, and improving capacity of waste treatment. Moreover, conducting further research on impact mechanism from various stakeholders, more environmental impacts, large temporal and spatial scales, and high quality of data may be necessary in the future.
\end{abstract}

Keywords: phosphorus, crop farming, farmers' behaviors, driving factors, sustainable management

\section{Introduction}

Crop production is fundamental to our existence, yet we are using up the world's supply of phosphorus (P),

*e-mail: wuhuijun414@gmail.com

an essential nutrient required for plant growth. Today, $\mathrm{P}$ is mostly produced by mined rock phosphate, which is becoming scarce and expensive [1]. While the global trade of phosphate rock is completely dependent on only several countries such as Morocco in the future, which will potentially limit global production [1, 2]. Meanwhile, $\mathrm{P}$ may accumulate in soils from excessive application of fertilizers relative to requirement of crops 
[3]. Excessive soil P levels will lead to high P losses in runoff, increasing the potential for surface water eutrophication [4-6]. P security is defined as ensuring that all farmers have access to sufficient $\mathrm{P}$ in the short and long term to grow enough food to feed a growing world population, while ensuring farmer livelihoods and minimizing detrimental environmental and social impacts [7]. Concerns about $\mathrm{P}$ scarcity and excess pollution have led to understanding of $\mathrm{P}$ security [2] and $\mathrm{P}$ vulnerability assessment [8], which has helped manage $P$ sustainably.

To manage $\mathrm{P}$ sustainably, we need an accurate understanding of how it moves through crop production and where $\mathrm{P}$ is stored. Thus, the first step is to trace and quantify these $\mathrm{P}$ flows in the farming processes. Early studies focused on quantifying $\mathrm{P}$ flows in agricultural production system for indentifying the characteristics of $\mathrm{P}$ loss or P use efficiency. $\mathrm{P}$ use efficiency is defined by $\mathrm{P}$ product output (e.g., grain harvest) divided by total $\mathrm{P}$ input (e.g., chemical fertilizer, organic fertilizer, irrigation, and seed) [9]. The quantitative method was first developed to calculate P loads from farming, mainly based on monitoring [10], Geographic Information System (GIS) [11], or soil erosion and P loss formulas [12]. Then mass-balance method was applied for evaluating $\mathrm{P}$ flows and $\mathrm{P}$ loss to water environment [13-15]. Concerning the lack of a systemic inquiry into the sources, flows and fate of $\mathrm{P}$ which can facilitate identification of key management points, substance flow analysis (SFA) was suggested. This method systematically assesses flows and stocks of one substance within a system that is defined in space and time and connects sources, pathways, intermediates and final sinks of the substance [16]. At present, researchers have published meaningful SFA results concerning $\mathrm{P}$ flows in agricultural production system on the global [17], national [4][18,19], watershed [20-22] or city [23, 24] level. As these methods mainly quantify $P$ flows, later studies began to concern $\mathrm{P}$ management relating with P use efficiency and P security [25-27]. However, these methods are often used as tools to understand $\mathrm{P}$ flows or cycling, seldom inherently providing information about the factors driving $\mathrm{P}$ flows. This may lead to the proposed measure to be general and stuffless.

Farmers' behaviors play the important role in managing agriculture production [28]. Meanwhile, these behaviors relating with agricultural production are not only influenced by farm-internal factors, but also driven by farm-external factors [29]. Thus, to provide sustainable $\mathrm{P}$ management, it is critical to understand which farmers' behaviors directly and indirectly drive $P$ flows and how these behaviors are affected by the potential factors. Mugandani and Mafongoya [28] investigate the smallholder farmers' behaviour towards the adoption of conservation agriculture. Wilson et al. [30] also stressed farmers' in-field practices were critical to reduce nutrient loading to recommended levels in Lake Erie. These studies focus more on farmers' behaviors or practices, while seldom pay more attention on the driving factors influencing farmers' behaviors or practices. Moreover, previous studies research the farmers' behaviors more qualitatively mainly based on reviewing previous research, while seldom highlight the need for a structured and systemic approach to identifying the relevant factors driving the behaviors. By assessing the importance of the driving factors affecting the farmers' conservation measures, Sattler and Nagel [31] quantitatively identified the importance of those measures to mitigate the environmental effects from agriculture. However, they seldom analyze the farmers' behaviors and their driving factors from the point of the nutrient elements, which are the key sources of the environmental impacts from agriculture as discussed above.

China has the largest world's population, and has to grow food to feed $22 \%$ of the world's population with only $7 \%$ of the world's arable land. Consequently, facing the challenges of food, crop production has substantially increased in China, which has resulted in P fertilizers being overused by farmers in crop production [32,33]. About $66 \%$ of phosphate rock ore mined was used to produce phosphate fertilizer. Though China has the $2^{\text {nd }}$ largest phosphate rock ore in the world, the high-quality ore being used for processing is limited [34]. Meanwhile, the production efficiency of $\mathrm{P}$ fertilizer is low: $8.3 \mathrm{~kg}$ of phosphate rock $\left(30 \% \mathrm{P}_{2} \mathrm{O}_{5}\right)$ is required to produce only $1 \mathrm{~kg}$ of $\mathrm{P}_{2} \mathrm{O}_{5}$ fertilizer [35]. The excessive use of $P$ fertilizers and uncontrolled exploitation of phosphate rock have led to serious environmental problems such as eutrophication of surface waters [36]. These trends pose serious challenges to $\mathrm{P}$ security in crop production in China. In fact, there are some studies analyzing the factors influencing farmers' nutrient management. For example, Daxini et al. [37] examined the psychological factors (beliefs and social pressure) factors on farmers' adoption of nutrient management practices. However, underlying socio-economic factors such as regulation and market may lead to an incomplete understanding of farmers' practices.

The study firstly identifies and analyzes farmers' behaviors impacting $\mathrm{P}$ security of farming, and then analyzes drivers of these behaviors. It could provide effective $\mathrm{P}$ management to mitigate $\mathrm{P}$ security and achieve sustainable agriculture. In view of the farming subject - farmers, the study selects Chaohu Watershed which has the typical agricultural features in China as the case study, analyzes the mechanism of farmers' behaviors affecting $\mathrm{P}$ security of crop farming. In particular, the aims of this study are the following: (1) to develop a quantitative model to determine the farmers' behaviors impacting P security of agricultural farming, (2) to identifies the key driving factors affecting these behaviors based on survey and literature, (3) to proposes $\mathrm{P}$ management practices to respond to the challenges in $\mathrm{P}$ security based on the previous analysis on mechanism of 'driving factors - farmers' behaviors - P security of farming'. 


\section{Materials and Methods}

\section{Study Area}

The study region 'Chaohu Watershed' is situated in the central of Anhui province of central China. The region covers an area of $13,350 \mathrm{~km}^{2}$, accounting for $10 \%$ of the province's total land area [38]. The total population of the watershed is approximately 9.64 million representing one of the most densely populated areas. About $70 \%$ of the region's area is in agricultural use that has typical agricultural features of central China. Though the phosphate rock reserves used to produce chemical fertilizers in the area are limited, the application of $\mathrm{P}$ fertilizer is heavy, resulting in the eutrophication processes in the lake watershed having become a serious issue [39]. Nonpoint source pollution from agricultural farmlands has been proven to be the primary nutrient sources for the lake [21]. As one of the five largest lakes in China, Chaohu Lake plays a central role in local environmental and societal development [40]. There are 33 tributary rivers running into Chaohu in the watershed, which contribute to transporting most $\mathrm{P}$-containing wastewater into Chaohu. The $\mathrm{P}$ use efficiency of agricultural production in the Chaohu Watershed is low overall [21].

\section{Logit and Probit Model}

The study analyzing the influences of farmers' behaviors on $\mathrm{P}$ security with crop farming is divided into two parts: one is to determine which farmers' behaviors mainly influence the $\mathrm{P}$ security, the other is to analyze how the key behaviors impact the $\mathrm{P}$ security. Thus, a multinomial logit (MNL) model and a multinomial probit (MNP) model are developed respectively.

Logit analysis is characterized by the prediction of probability of the event that either occur or not. The MNL model has received significant attention from researchers of economics, marketing, operations management and transportation science, and has motivated tremendous theoretical research and empirical validations in a large range of applications since it was first proposed and formulated by McFadden [41]. Given transformation allows the ideal relationship between dependent variable $\mathrm{y}$ and a vector of independent variables $\mathrm{x}$. If values of independent variable are very low the probability of the variable y close to zero and if the values of independent are high the probability of y close to one. Logistic regression uses categorically explained variable [42].

It is necessary to realize logit transformation within the logistic regression to establish this condition. In this study, it assumes the farmers' farming behaviors follow the MNL model. In the MNL model, the outcome or the dependent variable is coded ' 0 ' and ' 1 '. Considering the arable area of crops directly influencing the farming activities (etc. applying fertilizer and herbicide, draining, sowing, harvesting), the arable area of crops is selected to represent the dependent variable. Basing on the survey on Chaohu Watershed, the arable area being less than or equal to 0.2 ha is coded as ' 0 ', and that being more than 0.2 ha is coded as ' 1 '. Y is used to represent this dummy variable, the value of which is 0 or 1. The farmers' behaviors potentially affecting the $\mathrm{P}$ security of crop farming are defined as the independent variables. Thus the MNL model to illustrate the relation of farmers' behaviors and P security of crop farming is as equation (1) and equation (2).

$$
P_{i}=P\left(Y=1 / X_{i}\right)(i=1,2,3, \ldots, n)
$$

...where, $P_{i}$ denotes the probability of the influence of farmers' behaviors on $\mathrm{P}$ security in crop farming. $X_{i}(i=1,2,3 \ldots, n)$ means the i-th farmers' behavior.

$$
\ln \left(p_{i} /\left(1-p_{i}\right)\right)=\alpha_{0}+\sum_{i=1}^{n} \alpha_{i} X_{i}(i=1,2,3, \ldots, n)
$$

...where, $\ln \left(p_{i} /\left(1-p_{i}\right)\right.$ denotes whether the farmers' behaviors influence the $\mathrm{P}$ security or not, $\alpha_{0}$ represents the random component, $\alpha_{i}(i=1,2,3 \ldots, n)$ means the regression parameter specific to segment $i$.

The MNP model is used to analyze the influence degree of the key behaviors identified by MNL model. The MNP model is based on the multivariate normal distribution and is recommended in cases of independence among the irrelevant alternatives [43]. The MNP model is one form of a correlated binary response regression model that simultaneously estimates the influence of independent variables on - more than one - dependent variables. The dependent variable represents having impacts on $\mathrm{P}$ security (or one) or having no impact on $\mathrm{P}$ security (or zero) responses to the question regarding the importance of each farmers' behavior. The MNP model is showed in equation (3).

$$
\frac{1}{\sqrt{2 \pi}} \int_{-\infty}^{p} e^{-\frac{t^{2}}{2}} d t=\beta_{0}+\sum_{i=1}^{n} \beta_{i} X_{i}(i=1,2,3, \ldots, n)
$$

...where, $\frac{1}{\sqrt{2 \pi}} \int_{-\infty}^{p} e^{-\frac{t^{2}}{2}} d t$ is used to illustrate the degree of the impacts on $\mathrm{P}$ security by the behaviors identified by logit regression, $\beta_{0}$ represents the random component, $\beta_{i}(i=1,2,3 \ldots, n)$ means the regression parameter specific to segment $\mathrm{i}$.

\section{Data Collection}

It could be concluded from the studies calculating $P$ by using SFA method in Chaohu Watershed [21] [44-49], some farmers' behaviors are already being considered. The study selects 12 farmers' behaviors potentially impacting the $\mathrm{P}$ security in the farming system: application of seed, sowing method, drainage 
times, harvesting method, application of compound fertilizer, application of phosphate fertilizer, application of pesticide, application of herbicide, disposal of straw, disposal of livestock manure, disposal of residents manure, and times of skill training. The study divides these behaviors into several categories separately with data gained from survey questionnaires. The aim of the questionnaire is to reach a many full-time farmers in the watershed as possible to enable data and statements valid for the whole region. For the purpose, the study designed a questionnaire for farmers focusing on their cultivating activities. The interviewed farmers were 30 to 70 years old living in rural areas and being familiar with agricultural production practices. The study selected the year 2013 as the survey time. Considering the surveyed region, the study selected three representative towns for each county and three villages for each town, and interviewed six to eight farmers in

Table 1 . Setting of variable.

\begin{tabular}{|c|c|c|c|c|c|}
\hline Variable & Description & Category & Code & Frequency & Percent $(\%)$ \\
\hline \multirow{5}{*}{$\mathrm{X}_{1}$} & \multirow{5}{*}{ Application of seed } & No seed sowed & 0 & 18 & 2.7 \\
\hline & & $0<\mathrm{X}_{1}<=5 \mathrm{~kg}$ & 1 & 209 & 31.38 \\
\hline & & $5 \mathrm{~kg}<\mathrm{X}_{1}<=10 \mathrm{~kg}$ & 2 & 102 & 15.32 \\
\hline & & $10 \mathrm{~kg}<\mathrm{X}_{1}<=15 \mathrm{~kg}$ & 3 & 41 & 6.16 \\
\hline & & $X_{1}>15 \mathrm{~kg}$ & 4 & 296 & 44.44 \\
\hline \multirow{3}{*}{$\mathrm{X}_{2}$} & \multirow{3}{*}{ Sowing method } & No sowing & 0 & 51 & 7.66 \\
\hline & & Manual sowing & 1 & 608 & 91.29 \\
\hline & & Mechanical sowing & 2 & 7 & 1.05 \\
\hline \multirow{5}{*}{$\mathrm{X}_{3}$} & \multirow{5}{*}{ Drainage times } & $X_{3}=0$ & 0 & 224 & 33.63 \\
\hline & & $X_{3}=1$ & 1 & 79 & 11.86 \\
\hline & & $X_{3}=2$ & 2 & 143 & 21.47 \\
\hline & & $X_{3}=3$ & 3 & 118 & 17.72 \\
\hline & & $X_{3}>=4$ & 4 & 102 & 15.32 \\
\hline \multirow{4}{*}{$\mathrm{X}_{4}$} & \multirow{4}{*}{ Harvesting method } & No harvesting & 0 & 40 & 6.01 \\
\hline & & Manual harvesting & 1 & 154 & 23.12 \\
\hline & & Mechanical harvesting & 2 & 405 & 60.81 \\
\hline & & Mixed harvesting & 3 & 67 & 10.06 \\
\hline \multirow{5}{*}{$\mathrm{X}_{5}$} & \multirow{5}{*}{$\begin{array}{l}\text { Application of com- } \\
\text { pound fertilizer }\end{array}$} & No compound fertilizer applied & 0 & 68 & 10.21 \\
\hline & & $0<\mathrm{X}_{5}<=100 \mathrm{~kg}$ & 1 & 160 & 24.02 \\
\hline & & $100 \mathrm{~kg}<\mathrm{X}_{5}<=200 \mathrm{~kg}$ & 2 & 166 & 24.92 \\
\hline & & $200 \mathrm{~kg}<\mathrm{X}_{5}<=300 \mathrm{~kg}$ & 3 & 96 & 14.41 \\
\hline & & $\mathrm{X}_{5}>300 \mathrm{~kg}$ & 4 & 176 & 26.43 \\
\hline \multirow{5}{*}{$\mathrm{X}_{6}$} & \multirow{5}{*}{$\begin{array}{l}\text { Application of phos- } \\
\text { phate fertilizer }\end{array}$} & No phosphate fertilizer applied & 0 & 574 & 86.19 \\
\hline & & $0<\mathrm{X}_{6}<=100 \mathrm{~kg}$ & 1 & 40 & 6.01 \\
\hline & & $100 \mathrm{~kg}<\mathrm{X}_{6}<=200 \mathrm{~kg}$ & 2 & 23 & 3.45 \\
\hline & & $200 \mathrm{~kg}<\mathrm{X}_{6}<=300 \mathrm{~kg}$ & 3 & 9 & 1.35 \\
\hline & & $\mathrm{X}_{6}>300 \mathrm{~kg}$ & 4 & 20 & 3 \\
\hline \multirow{5}{*}{$\mathrm{X}_{7}$} & \multirow{5}{*}{$\begin{array}{l}\text { Application of pes- } \\
\text { ticide }\end{array}$} & No pesticide applied & 0 & 380 & 57.06 \\
\hline & & $0<\mathrm{X}_{7}<=2.5 \mathrm{~kg}$ & 1 & 166 & 24.93 \\
\hline & & $2.5 \mathrm{~kg}<\mathrm{X}_{7}<=5 \mathrm{~kg}$ & 2 & 60 & 9.01 \\
\hline & & $5 \mathrm{~kg}<\mathrm{X}_{7}<=7.5 \mathrm{~kg}$ & 3 & 28 & 4.2 \\
\hline & & $X_{7}>7.5 \mathrm{~kg}$ & 4 & 32 & 4.8 \\
\hline
\end{tabular}


Table 1. Continued.

\begin{tabular}{|c|c|c|c|c|c|}
\hline \multirow{5}{*}{$\mathrm{X}_{8}$} & \multirow{5}{*}{$\begin{array}{l}\text { Application of her- } \\
\text { bicide }\end{array}$} & No herbicide applied & 0 & 397 & 59.61 \\
\hline & & $0<\mathrm{X}_{8}<=2.5 \mathrm{~kg}$ & 1 & 226 & 33.93 \\
\hline & & $2.5 \mathrm{~kg}<\mathrm{X}_{8}<=5 \mathrm{~kg}$ & 2 & 20 & 3 \\
\hline & & $5 \mathrm{~kg}<\mathrm{X}_{8}<=7.5 \mathrm{~kg}$ & 3 & 4 & 0.6 \\
\hline & & $\mathrm{X}_{8}>7.5 \mathrm{~kg}$ & 4 & 19 & 2.85 \\
\hline \multirow{6}{*}{$\mathrm{X}_{9}$} & \multirow{6}{*}{ Disposal of straw } & No straw & 0 & 71 & 10.66 \\
\hline & & Abandoned & 1 & 458 & 68.77 \\
\hline & & Burned for cooking & 2 & 91 & 13.66 \\
\hline & & Used as feed & 3 & 32 & 4.81 \\
\hline & & Produced methane & 4 & 2 & 0.3 \\
\hline & & Sold & 5 & 12 & 1.8 \\
\hline \multirow{5}{*}{$\mathrm{X}_{10}$} & \multirow{5}{*}{$\begin{array}{l}\text { Disposal of live- } \\
\text { stock's manure }\end{array}$} & No livestock manure & 0 & 251 & 37.69 \\
\hline & & No disposal & 1 & 55 & 8.26 \\
\hline & & Applied to field & 2 & 353 & 53 \\
\hline & & Used as feed & 3 & 1 & 0.15 \\
\hline & & Produced methane & 4 & 6 & 0.9 \\
\hline \multirow{5}{*}{$\mathrm{X}_{11}$} & \multirow{5}{*}{$\begin{array}{c}\text { Disposal of residents' } \\
\text { manure }\end{array}$} & No residents manure & 0 & 64 & 9.61 \\
\hline & & Applied as fertilizer & 1 & 533 & 80.03 \\
\hline & & Flowed into digestion tank & 2 & 28 & 4.21 \\
\hline & & Swept by nightstool & 3 & 29 & 4.35 \\
\hline & & Produced methane & 4 & 12 & 1.8 \\
\hline \multirow{5}{*}{$\mathrm{X}_{12}$} & \multirow{5}{*}{$\begin{array}{l}\text { Times of skill train- } \\
\text { ing }\end{array}$} & $X_{12}=0$ & 0 & 466 & 69.97 \\
\hline & & $X_{12}=1$ & 1 & 77 & 11.56 \\
\hline & & $X_{12}=2$ & 2 & 65 & 9.76 \\
\hline & & $X_{12}=3$ & 3 & 27 & 4.05 \\
\hline & & $\mathrm{X}_{12}>=4$ & 4 & 31 & 4.66 \\
\hline
\end{tabular}

each village. Finally the response rate was $97.65 \%$, and 666 usable questionnaires were recovered as a result of uncontrollable factors (e.g., cooperation, traffic, and weather). The setting of the farmers' behaviors or the variables is described in Table 1.

\section{Results and Discussion}

\section{Definition of the Key Behaviors Impacting P Security}

To defy the key behaviors impacting the P security, the estimated results from the binary logit regression are overly presented in Table 2 . In the logit, the estimated deviations of these variables are various, indicating that the variables indeed vary.

It can be concluded from the probability level below $5 \%$ that $\mathrm{X}_{1}, \mathrm{X}_{2}, \mathrm{X}_{4}, \mathrm{X}_{5}, \mathrm{X}_{6}, \mathrm{X}_{10}$ greatly impacted the $\mathrm{P}$ security in the farming system. As sowing must consumes many seeds (about $0.36 \mathrm{t} / \mathrm{ha}$ ) containing $\mathrm{P}$ and occupies cropland, both the application of seed and the sowing behavior directly impacted the $\mathrm{P}$ flow of the farming. Meanwhile, it is found from survey that the application of chemical fertilizers producing from fertilizer industries was very high in the watershed. This is similar to the results of a Chinese investigation that less than $40 \%$ of farmers apply $\mathrm{P}$ fertilizer rationally, and more than $20 \%$ of farmers apply $\mathrm{P}$ in excess [9]. The high rate of fertilizer application exceeds crop absorption, resulting in great $\mathrm{P}$ loss from the farming system via erosion/runoff [50]. Thus the applications of compound fertilizer and phosphate fertilizer also had great influences on the $\mathrm{P}$ security. It should also be noted the $\mathrm{P}$ discharged to water would be great when harvesting. This is mainly contributed to two reasons. Firstly, a few crops would be wasted inevitably when they are harvested. Secondly, as the great number of 
Table 2. Results from the binary logit regression.

\begin{tabular}{|c|c|c|c|c|}
\hline Variable & Coefficient & Std. Error & z-Statistic & Prob. \\
\hline$\alpha_{0}$ & -1.622 & 0.435 & -3.726 & 0 \\
\hline $\mathrm{X}_{1}$ & 0.279 & 0.08 & 3.493 & 0.001 \\
\hline $\mathrm{X}_{2}$ & -1.47 & 0.452 & -3.253 & 0.001 \\
\hline $\mathrm{X}_{3}$ & 0.023 & 0.07 & 0.324 & 0.746 \\
\hline $\mathrm{X}_{4}$ & 0.425 & 0.165 & 2.578 & 0.01 \\
\hline $\mathrm{X}_{5}$ & 0.779 & 0.095 & 8.222 & 0 \\
\hline $\mathrm{X}_{6}$ & 0.515 & 0.165 & 3.127 & 0.002 \\
\hline $\mathrm{X}_{7}$ & 0.074 & 0.126 & 0.584 & 0.56 \\
\hline $\mathrm{X}_{8}$ & 0.116 & 0.187 & 0.618 & 0.537 \\
\hline $\mathrm{X}_{9}$ & -0.022 & 0.113 & -0.197 & 0.844 \\
\hline $\mathrm{X}_{10}$ & 0.249 & 0.1 & 2.495 & 0.013 \\
\hline $\mathrm{X}_{11}$ & -0.046 & 0.151 & -0.302 & 0.763 \\
\hline $\mathrm{X}_{12}$ & 0.054 & 0.093 & 0.581 & 0.561 \\
\hline
\end{tabular}

crop is taken away, the overmuch nutrient accumulated in the soil would be lost to the water via erosion and runoff. Table 2 also shows the disposal of livestock's manure had the considerable relationship with the $\mathrm{P}$ loss. It is found from the survey in Chaohu Watershed that there are two kinds of livestock breeding exist: large-scale breeding and domestic breeding. However, the disposal capabilities of the livestock manure of these two livestock breeding were inefficient. Meanwhile, most of the manure was applied to the field with much manure flowing into environment. This phenomenon is general in China, like Ma et al. [51] and the $1^{\text {st }}$ National Census of Pollution Sources in China indicated that $55 \%$ and $56 \%$ of the $\mathrm{P}$ in livestock excrement was lost.

It could be concluded that other behaviors such as drainage times, application of pesticide and herbicide, disposal of straw and residents' manure, and times of skill training had no obvious relationship with $\mathrm{P}$ security. As the frequencies of the drainage times were similar, there's no obvious difference among the farmers' draining. Meanwhile, there is a local law prohibiting the use of pesticides containing $\mathrm{P}$ and many pesticides are produced will low P-containing, hence the application of the pesticides containing pesticide and herbicide had few impact on the $\mathrm{P}$ security when farming. Moreover, by investigating the straw was often abandoned to the field and directly burned (about 68.77\%), which would result in much $\mathrm{P}$ stored in the field and less flowed to water. Concerning there's many large-scale breeding enterprises in the watershed, and their capabilities and instruments of disposing of manure were backward, thus much manure was discharged directly to the environment. On the contrary, the residents' manure was often discharged to the rural lavatories and then was applied to the field, which would discharge less $\mathrm{P}$ than the livestock breeding. In fact, the proper collection and processing of wastes from breeding and residents' living in rural regions have many economic barriers. Finally, almost $70 \%$ of farmers hadn't accepted the skill training, and many farmers didn't think the training is helpful, either. Consequently, it seems the skill training had inadequate relationship with the $\mathrm{P}$ flow.

\section{Degree of the Impacts with the Key Behaviors}

Table 3 shows the results from the probit regression which is used to determine the degree of the impacts on $\mathrm{P}$ security by the key behaviors identified by logit regression. It could be seen the results from the probit regression is similar to that from the logit regression. It is illustrated from the coefficients in Table 3 that $\mathrm{X}_{2}$ mostly impacted the $\mathrm{P}$ security. Moreover, the manual sowing had greater impact than the mechanical sowing as most of the seed was sown by the manual sowing showed in Table 1 (91.29\%). In fact, the manual sowing often sow the seed casually and disorderly, which will consume much more seeds than that with mechanical sowing. Meanwhile, sowing needs the land use, which strongly affects overall flows of P [32]. The applications of compound fertilizer and phosphate fertilizer also influenced the $\mathrm{P}$ security obviously. $\mathrm{P}$ accumulation resulting from over application of $\mathrm{P}$ fertilizers may cause phosphate saturation in soils, a state which is characterized by the increased leaching and runoff of added P [52-54]. As discussed above, the amount of fertilizers had the positive correlation with the $\mathrm{P}$ security. It was surveyed $71.13 \%$ and $23.84 \%$ of the cropland were planted with rice and wheat, which needed to consume more fertilizers than other crops. It was also found the chemical fertilizers were supplied in every town, thus the farmers were easy to buy them. With the economic development and the urbanization of Chaohu Watershed, the farmers' income also increases quickly, which urges farmers to buy more chemical fertilizers to apply. By investigation it showed the farmers more likely to consider the effect and the brand of the chemical fertilizers than their prices. It is also need to notice that the residents generally containing the aged people and children are usually stayed in the home, and the young and middle-aged male residents often work outside. This situation leads the residents' living structure to be simpler, and the labor force for farming is inadequate. With the farmers also feel difficult and dirty to use the organic fertilizer, the P-chemical fertilizers are used increasingly, even exceeding the adsorption of the crops. In addition, the price of the chemical fertilizers also affected the fertilizer application. Metson et al. [55] noted when $\mathrm{P}$ fertilizer prices increase, farmers in the area will consult agricultural extension officers for advice on methods to minimize their use of $\mathrm{P}$ fertilizers without reducing yield. The application of fertilizers also relates with the application skill (including amount and timing 
Table 3. Results from the binary probit regression.

\begin{tabular}{|c|c|c|c|c|}
\hline Variable & Coefficient & Std. Error & z-Statistic & Prob. \\
\hline$\beta_{0}$ & -0.931 & 0.249 & -3.737 & 0 \\
\hline$X_{1}$ & 0.168 & 0.048 & 3.542 & 0 \\
\hline$X_{2}$ & -0.864 & 0.263 & -3.285 & 0.001 \\
\hline$X_{3}$ & 0.013 & 0.041 & 0.313 & 0.754 \\
\hline$X_{4}$ & 0.241 & 0.096 & 2.5 & 0.012 \\
\hline$X_{5}$ & 0.447 & 0.052 & 8.579 & 0 \\
\hline$X_{6}$ & 0.25 & 0.086 & 2.921 & 0.004 \\
\hline$X_{7}$ & 0.038 & 0.071 & 0.534 & 0.593 \\
\hline$X_{8}$ & 0.091 & 0.107 & 0.844 & 0.399 \\
\hline$X_{9}$ & -0.021 & 0.068 & -0.315 & 0.753 \\
\hline$X_{10}$ & 0.147 & 0.059 & 2.492 & 0.013 \\
\hline$X_{11}$ & -0.019 & 0.087 & -0.219 & 0.827 \\
\hline$X_{12}$ & 0.04 & 0.054 & 0.733 & 0.464 \\
\hline
\end{tabular}

of fertilization, and soil properties), which is mainly due to the access to information and the education level. As farmers live in rural area, in where the information referring to farming is hard to obtain and most of them seldom accept the skill training, their farming skill including fertilizer application is backward. On the other hand, the farmers having education level of junior high school occupied about $83.70 \%$, which also affected the application level.

As noted above, the harvesting method also impacted the $\mathrm{P}$ security in the farming system. Meanwhile, most of the crops were harvested by mechanical harvesting, which was more efficient than manual harvesting. More crops were moved from the field with less abandoned with the mechanical harvesting. Thus more nutrients would flow into environment with erosion and runoff. Moreover, the prices of the seeds were quite cheap, which drived farmers to buy more seeds. Then sowing more seeds at the same time would consume more croplands and more fertilizers, which also absolutely would lead to more P being discharged to environment. It is also showed from the questionnaires that about $53.0 \%$ farmers applied livestock's manure to the field. This result is in accordance with the results from Ma et al. [9] and the $1^{\text {st }}$ National Census of Pollution Sources in China, which respectively indicated that $55 \%$ and $56 \%$ of the $\mathrm{P}$ in livestock excrement was lost. In addition, to promote the production of livestock breeding, the livestock farmers therefore selected feed with high $\mathrm{P}$ concentrations to feed stuff. This increased $\mathrm{P}$ input via feed additives reduced the $\mathrm{P}$ use and resulted in more manure containing P being discharged. The P loss from livestock to the environment exceeded the manure applied to fields. Thus, a large fraction of the manure was discharged into the environment and not used as fertilizer. The livestock manure is either reused as a fertilizer for crops, "lost" from the livestock breeding subsystem to the non-agricultural land or lost to water mainly via leakage.

\section{Categories of Factors Driving Behaviors}

Based on the analysis of the definition and degree of the impacts of the key behaviors illustrated above, the study identifies four categories that drive the behaviors strongly influencing the P security (Fig. 1). Evaluation these categories may provide effective solutions for $\mathrm{P}$ management in the farming system.

(i) Market and purchasing. The market factors refer to the demanding and supplying of goods containing $\mathrm{P}$ such as chemical fertilizers and seeds. While purchasing factors mainly include farmers' income, prices of those goods, and farmers' purchase inclinations. It was shown most of the crops in the region were grain crops, which demanded more fertilizers than other crops. In addition, the supply of the chemical fertilizers and the feed were adequate in every village. Thus farmers inclined to buy more chemical fertilizers to substitute organic fertilizers. In particular, the purchasing power influenced by the price of the P-containing goods and the farmer's income also affected the use of chemical fertilizers obviously. As discussed above, with stable prices of the chemical fertilizers and increase of the farmers' income, farmers preferred to use chemical fertilizers than organic fertilizers which were considered to be dirty and labor consumed to be applied to field. This analysis is in accordance with Yuan et al. [48] study. It is also noted the farmers inclined to buy chemical fertilizers having good effects and famous brands, not being impacted by their prices only. In fact, in the long term, additional inorganic $\mathrm{P}$ supply is necessary, in addition to organic amendments. Moreover, the higher the farmers' income, the greater famers' capacity to adopt modern farming practices including integrated nutrient management [56].

(ii) Personal characteristics. The factors of personal characteristics mainly include skill of application and sowing, acceptance of skill training, education level, labor force, and age. Han et al. [57] noted increasing farmers' knowledge about proper fertilizer application rates, based on the best scientific information available (including amount and timing of fertilization, and soil properties), is an effective way to decrease downstream pollution. Dessart et al. [58] presented a conceptual model summarizing behavioral factors that influence farmers' decision making to adopt environmentally sustainable practices, and also noted knowledge and perceived benefit, as cognitive factors, are expected to foster participation in agri-environmental schemes. In addition, the skill of application and sowing impacts obviously on the proper fertilizer application rate, which significantly elevated P loss to surface water [59]. However, as discussed above, the farmers' acceptance of skill training was low in the watershed, which correspondingly resulted in the heavy application 
of fertilizers. It also showed that most of the farmers only had the education level of junior high school, and seldom had the opportunity to accept the skill training. Their knowledge about farming might be inadequate. Nanda et al. [56] also noted rural literacy (\% farmers with at least five years of schooling) is helpful for the farmers to understand agronomic methods, to benefit from government programs, and to better respond and adapt to information. Moreover, as most rural residents staying in the countryside were children and aged men, there's inadequate labor force to farm.

(iii) Planting situation. Planting situation comprises land use, mechanization level, and infrastructure. Land use differentiates activities having distinct, characteristic P flows such as fertilizer application for agriculture, and thus land use composition strongly affects overall flows of P [60]. Proportion of cultivated area to total geographical area is generally used to measures a country's dependence on agriculture: the higher the value, the greater the dependence on $\mathrm{P}$ [56]. Li et al. [61] also found both the proportion of cultivated land and the intensity of phosphate fertilizer used in cultivated land showed a positive correlation with the net anthropogenic $\mathrm{P}$ inputs in a studied basin in China. Chaohu Watershed, most of the agricultural land was planted with rice and wheat, which consumed much more fertilizers than others. While the chemical fertilizers especially the compound fertilizers using for these two crops accounted for $98.13 \%$ of total compound fertilizers, based on investigation. Moreover, the mechanization level also influences the efficiency of farming including sowing and harvesting [62]. The Ministry of Agriculture of China (MOA) [63] showed mechanization rate of farming, breeding, and harvesting has broken through $60 \%$ in 2014. By investigation we found the manual sowing was mainly

Driving factors

Farmers' behaviors

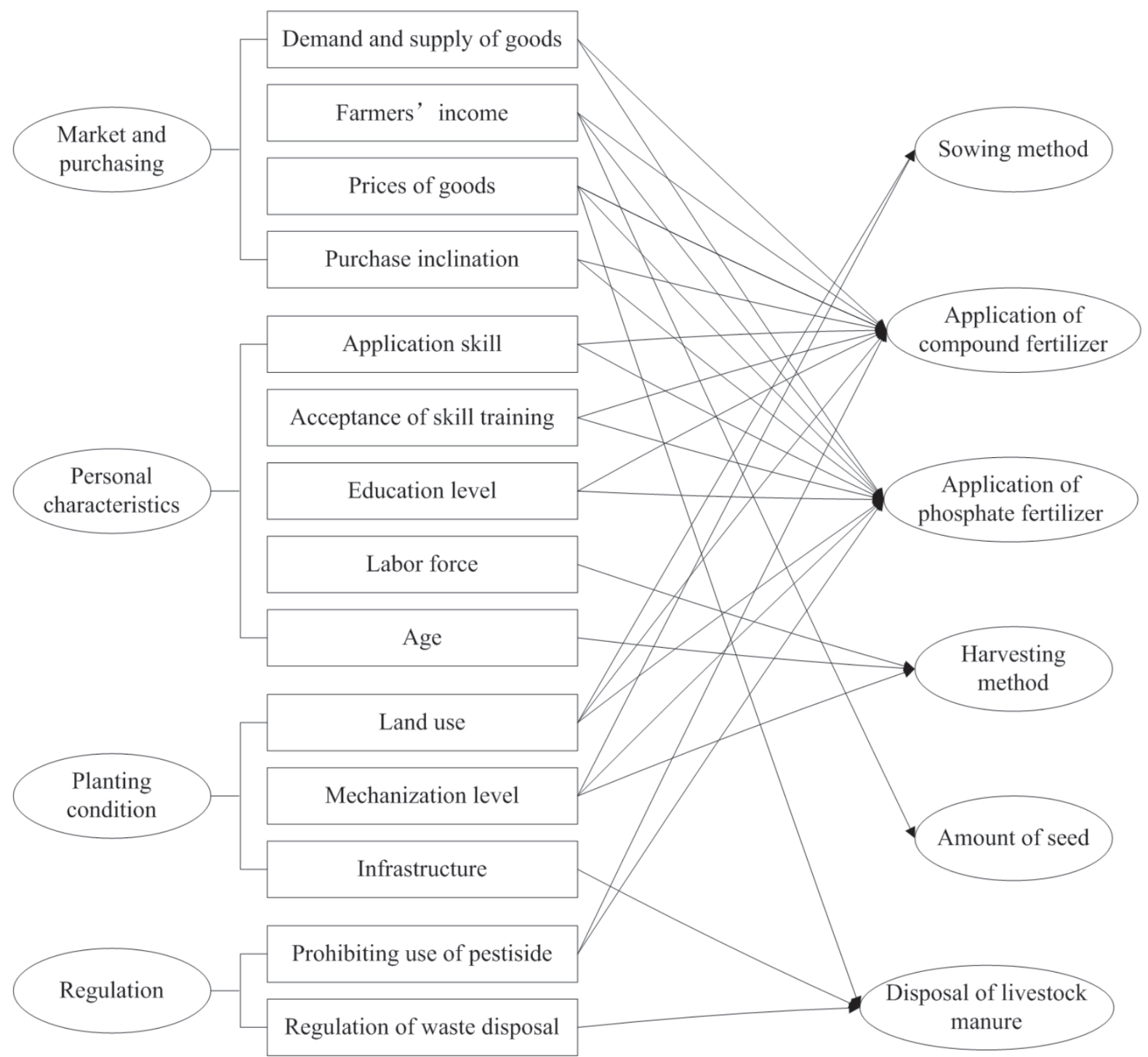

Fig. 1. Categories of driving factors affecting farmers' behaviors. 
used when sowing in Chaohu watershed, while the machines were mainly used when harvesting. Thus sowing and harvesting had the opposite effects on $\mathrm{P}$ security as discussed above. Park et al. [64] shown that simple mechanization (in the form of a chest-mounted seed and fertilizer spreader) caused yield efficiencies to be positive and significant for nitrogen and phosphate. Seedling density also increased with an increase in seed rate using this method. Compared to hand seeding and application, mechanization also shown its responses to a more precise input application, labor efficiency, and more predictable profits. Furthermore, as Metson et al. [65] indicated, infrastructure can also direct flows of P. It is noticed the sewage infrastructures in the rural areas and breeding enterprises were backward, which resulted in much rural residents' manure and livestock's manure directly being applied to field of flowed to the environment, increasing $\mathrm{P}$ load to the environment.

(iv) Regulation. Regulation clearly had an impact of $\mathrm{P}$ flows. As many pesticides containing $\mathrm{P}$ were prohibited to use, the impacts of applying pesticides on $\mathrm{P}$ security was unobvious. In addition, both training on environmental protection and regulation of waste disposal were absent in most breeding enterprises, which lead to inefficient disposal of wastes. In fact, previous research has found farmers' preferences depend not only on characteristics of agri-environmental contracts but also on objectives of the policy [66]. Schulz et al. [67] showed that specialized arable farms on highly productive land and intensive dairy farms are most likely to implement pro-environmental measures and voluntarily forgo part of their single payment entitlements. The impacts of regulation on farming can also be illustrated from other regions. For example, in Phoenix of USA, over-application of $\mathrm{P}$ on agricultural soils can be attributed in part to national Environmental Protection Agency laws on nutrient application that are based on the local limiting nutrient [55].

\section{Implications for Sustainable P Management}

The results above need to be considered when sustainable $\mathrm{P}$ management is proposed. Understanding how to influence farmers' behaviors through changing their key driving factors in the context of such $\mathrm{P}$ management is crucial. Therefore, the following measures should be paid increased attention.

\section{Improve Mechanization Level of Sowing and Application}

The results illustrate that sowing method, fertilizer applications, and harvesting method mostly impact $\mathrm{P}$ security of farming. The results also show that mechanization affects these key behaviors. Thus, improving the mechanization level of sowing and application are important. Generally a Chinese farm is too small to solely support machinery such as harvester.
However, if they cooperate to increase the farm size and share the cost of machinery, the operation cost would be decreased, and the mechanization level would be raised in turn [68]. Li et al. [69] also noted that larger farmers with more lands tend to adopt the most efficient technologies, which could increase profits with less pollution from fertilizers and pesticides. In recent years, some Chinese farmers tend to rent more lands given constraint of land sale market and also rely on machine services instead of purchasing machines when agricultural wages increase [70]. In many villages in China including Chaohu Watershed, households have the rights to transfer their lands to another household or firm. By the end of June in 2016, about 30 million ha of cultivated land in China was rented out, accounting for over $1 / 3$ of total cultivated land [71]. Increasing farm size will accelerate mechanization, which will help to mitigate the non-point source pollution $[72,73]$.

\section{Raise Environmental Awareness Amongst Farmers}

The results suggest that providing well reasoned and logical message should be effective in persuading farmers to adopt some effective measures to change the agricultural environment. This also greatly drives farmers to sow seed, apply fertilizer, and harvest grain, which greatly impact $\mathrm{P}$ security of farming. However, by investigation it was found farmers were not concerned with the agricultural contribution to environmental impact. Some farmers do not employ a systemic approach, focusing only on activities on their farm. Macintosh et al. [74] indicated that raising awareness and changing perceptions are the key activities to achieve $\mathrm{P}$ sustainability. Considering the demand and supply of fertilizers determine the use of fertilizers, farmers should buy chemical fertilizers according to the real demand of the crops. For obtaining the message about the need for crops, they should consult agricultural technicians or study from materials relating with farming.

\section{Increase Efficiency of Fertilizer Use}

Following sowing method, fertilization contributes the second greatest impact on P security of the farming system. Currently, fertilizer $\mathrm{P}$ is the primary source of dissolved $\mathrm{P}$ in runoff from Chinese paddy fields [59]. From the discussion on the factors driving fertilization, improve the application skill is essential. Farmers must use fertilizers appropriately and timely to maintain agricultural productivity and minimize $\mathrm{P}$ loss [75]. Zhang [76] suggested optimizing $\mathrm{P}$ application rate by replacing $\mathrm{P}$ level recommendations resulting from traditional methods (based on fertilizer response curves or P balances) with recommendations from new monitoring methods that establish soil $\mathrm{P}$ at a suitable level and balance the supply and demand of P. A range of soil P testing procedures (soil test P, STP) were 
also developed and calibrated to crop yield response across widely differing landscapes [77]. There is also growing evidence that using phosphorus activators (e.g. phosphate solubilizing microorganisms, phosphatase enzymes) can promote phosphate release from soil and, hence, have potential for mitigating global P crisis [78]. Moreover, best management practices (BMPs) have been suggested to minimize P loss and promote water quality in many agricultural areas including watershed [79]. In addition, the livestock's manure should be applied evenly to the field. The weather for application should also be concerned by the farmers. Malmaeus and Karlsson [80] showed spreading manure on farmlands in autumn is associated with higher risks for nutrient leakage to water compared to manure spreading in springtime, since the ground is unprotected by vegetation in winter and $\mathrm{P}$ may be transported by melting water. Furthermore, information provision through farmers' education and skill training may offer means to manage P. For example, for reducing the diffuse pollution from agriculture, farmers in UK have been educated on best practices and encouraged to reduce overall fertilizer applications and maintain soils at optimum $\mathrm{P}$ levels, which reduces the risk of $\mathrm{P}$ runoff to water whilst maintaining high yields. Through this measure, overall $\mathrm{P}$ fertilizer applications have decreased from over $200.0 \mathrm{kt} \mathrm{P} / \mathrm{yr}$ in 1970 to around $70.0 \mathrm{kt} \mathrm{P} / \mathrm{yr}$ in 2009 [80].

\section{Optimize Planting Condition}

Apart from mechanical level, land use also impact the three behaviors mostly impacting $\mathrm{P}$ security: sowing method, application of compound fertilizer, and application of phosphate fertilizer. As in Chaohu Watershed, the grain crops account most of the farmland and the fertilizer, the agriculture production structure is suggested to be adjusted. Farmers could plant more economic crops such as vegetables and fruits which consume less fertilizer. In addition, crop plants grown under field conditions must co-optimize their resource allocation for acquisition of several limiting resources, which may be unevenly distributed in space and time [81]. Thus, the crops should be planted basing on the soil conditions. Meanwhile, the irrigation and drainage should also in accordance with the weather. Lynch [82] showed the efficiency of freshly applied P fertilizer can be as low as 3\% under water-limiting conditions, whereas it increases to $30 \%$ in higher rainfall seasons. Moreover, the mechanization for sowing and harvesting should be improved through purchasing more advanced machines permitted by the farmers' income, and overhauling the machines regularly. Concerning the lack of the labor force in rural areas, the farmers are also suggested to hire other farmers or subcontract their farmlands for utilizing the farmlands efficiently. Actually, this planting pattern has been implemented in some regions of China, including Chaohu Watershed.

\section{Improve Capacity of Waste Treatment}

Livestock manure shared a significant part of the $\mathrm{P}$ loss and is the uncontrolled $\mathrm{P}$ output to environment, which is mainly resulted from the arbitrary reuse of the manure to the field and the backward capacity of waste treatment in the breeding enterprises. As discussed above, infrastructure of waste disposal and regulation of waste diposal are the main factors driving disposal of livestock manure, which is nonnegligible behavior impacting $\mathrm{P}$ security of farming. Thus, the farmers should not only control the number of livestock but also apply the manure properly as discussed above. Meanwhile, there are some studies showed adding traditional coagulants such as aluminum chloride to animal feed has also been shown to reduce phosphorus run-off from applied manure [83, 84]. Buda et al. [85] also noted that amending manure with rare metal chlorides reduces solubility of phosphorus compounds in surface applied manure, which in turn reduces runoff. While the cost and the operation of these measures may be weighed and considered by the famers, with the guidance of the technicians. Furthermore, like Schröder et al. [86] suggested that the livestock farmers can reduce the manure by supplying less feed-P the older the livestock gets, by tuning the daily ration of individual livestock to their actual production level, and by the use of artificial enzymes, which can improve the availability of feed-P. Moreover, the capacity of disposing waste in the breeding enterprises and rural areas should also be seriously concerned. Walan et al. [1] also indicated that recycling and reusing phosphorus at a higher extent would both limit environmental impacts as well as making the resources available longer. Thus, collecting manure at the source will reduce $\mathrm{P}$ entering the wastewater treatment plant with less energy and at lower costs.

Meanwhile, returning organic wastes to agricultural land also reduces the amount of wastes to be disposed of [87]. Concerning the barriers of disposing the wastes from breeding and rural residents' living, Ma et al. [88] suggested the establishment of a high-technology processing system, the household wastes sorting, and the operation of organic waste markets. And besides, it is necessary to strengthen staffs and farmers' awareness on green production and consumption through education and training. They also should help local governments and enterprises establish stronger regulations integrated with production, recycling, incineration, land filling, and biological treatment.

\section{Improve Farmers' Education and Income}

As noted above, both farmers' education and income drive farmers to apply fertilizers and disposing livestock manure. In 2020, Chinese government issued Central Document No.1 [89] and highlighted again that farmers' income growth is the fundamental and coreproblem in "agriculture-rural areas-farmers" work 
of the central document. Especially facing some viruses such as the novel coronavirus, swine fever, and avian influenza, how to ensure the food supply and farmers' income is a big challenge. Central Document No. 1 also claimed improving rural people's education level. The measures include strengthening rural boarding school's construction, improving conditions for running schools and teaching quality, etc. To improve farmers' income, Chand [90] suggested some measures, such as increasing crop productivity, using resources more efficiently, improving the supply chain, and switching to high-value crops. These measures could be initiated through crop insurance, minimum support prices, improved rural infrastructure for transport and storage, subsidies, and better management of the entire chain from sowing to marketing. Epper et al. [91] suggested that encouraging the investment of some of the available labour force into off-farm activities could also help to diversify income sources and ensure cash would be available to purchase inorganic fertilizers. There are also several research studies [92, 93] evaluating scheme and proposed strategic approaches to potentially achieve the given targets.

In order to improve P management more effectively, it is clear that farmers need to adopt multiple forms of measures in combinations to the above implications, such as preventing erosion and runoff, maintaining soil quality, changing residents' dietary pattern, expensing use channel of manure, etc.

\section{Limitations of the Analysis}

While this analysis describes the mechanism of farmers' behaviors affecting $\mathrm{P}$ security of crop farming in Chaohu Watershed, several methodological limitations of this study must be addressed in future research.

The study only analyzes the farmers' behaviors and their driving factors affecting the $\mathrm{P}$ security in the farming system. In fact, the external factors such as industrial structure adjustment, agricultural policy, natural environment, residents' consumption pattern, import and export trade, etc. also impact the P security $[28,31]$. In future research, the various behaviors related with farmers, government, enterprises, and residents, and their driving factors should be considered comprehensively for proposing more effective $\mathrm{P}$ management.

In addition, the study focuses on analyzing the drivers affecting $\mathrm{P}$ flows related with $\mathrm{P}$ resource depletion and eutrophication, seldom consideres other environmental impacts such as climate change, land use, ecosystems and biodiversity, which also influence the $\mathrm{P}$ security. For example, Schoumans et al. [94] suggest that climate smart $\mathrm{P}$ management measures are needed to reduce the expected deterioration of surface water quality resulting from climate-change-induced societal P losses.
While the year 2013 was selected as the static year due to highest data availability, the annual variations can occur with the conditions of farming. Although the information about farmers' farming skill and habit were collected basing on the farmers' experience for many years, the availability of other sources of data limit the base year in this study. At the same time, as there may be large discrepancies between the $\mathrm{P}$ behaviors and drivers for different types of farming system, it may thus not be applicable when making $\mathrm{P}$ management strategies on a regional scale.

The results of the study also have some data uncertainties. Firstly, the data were mainly collected from questionnaire survey and interviewing with farmers and rural residents, whose education level and the communication with investigators would influence the answers greatly. Meanwhile, when surveying the rural residents, it is found that their vague answers about the waste disposal and the inadequate knowledge of environmental protection would cause deviation to the data. Moreover, the statistical data have intrinsic uncertainties, which are difficult to assess without further information. For example, the categories of the variables in the model were determined mainly based on the frequency of every data category and the authors' judgment from experience, which may results in deviation of the results. For minimizing the data uncertainties, Wu et al. [46] suggest some measures, such as increasing the amount of questionnaires, expanding the range of surveyed regions and people, educating and popularizing the interviewees about the knowledge related with the questionnaires, and collecting more literature and materials, etc.

\section{Conclusions}

Sustainable P management is important to improve $\mathrm{P}$ security of farming system. Increasing understanding of farmers' behaviors and their driving factors is the key to implementing the $\mathrm{P}$ management. The study analyses the farmers' behaviors and their drivers affecting $P$ security of farming by applying MNL model and MNP model. The results show the farmers' behaviors including sowing method, application of compound fertilizer, application of phosphate fertilizer, harvesting method, application of seed, and disposal of livestock manure have greatly impacted the $\mathrm{P}$ security in the farming system based on MNL model, in turn. This was mainly due to cropland occupied by the sowed seed, low P use-efficiency of application of fertilizers, mechanical harvesting, and low disposal of livestock's manure. Concerning the degrees of the driving factors impacting on these key behaviors through MNP model, these six behaviors identified by MNL model also impacted the $\mathrm{P}$ security more greatly than other behaviors according to the same order. While the factors such as farmers' income, prices of goods, application skill, acceptance 
of skill training, mechanization level, and regulation of waste disposal, etc. were found to obviously influence the famers' behaviors driving $\mathrm{P}$ security, and these factors were classified into four categories: market and purchasing, personal characteristics, planting condition, and regulation.

With identifying and analyzing the key behaviors and the driving factors affecting phosphorus security of farming system, the study draw attention to the implications for managing P. To summarize, improving mechanization level, raising farmers' environmental awareness, increasing efficiency of fertilizer application, optimizing planting condition, and improving capacity of waste treatment are required. The study also highlighted that further research is necessary to analyze more behaviors from various stakeholders, consider more environmental impacts, enlarge temporal and spatial scales, and minimize data uncertainty.

Finally, as Chaohu Watershed has many typical features of agriculture in central China, the farmers' behaviors and their drivers affecting the $\mathrm{P}$ security of farming might reflect those of other regions of China. Thus, the study not only provides a basis to efficient use of $\mathrm{P}$ but also proposes the means to develop sustainable agriculture in other regions.

\section{Acknowledgements}

This study was funded by National Natural Science Foundation of China (72074003), Key Project on Research and Development of Anhui Province (202004i07020012), Anhui Natural Science Fund for Distinguished Young Scholars (1608085J09), and Project Plan of 'Lift Project for Young Scholars' of Anhui University of Science and Technology (2018).

\section{Conflict of Interest}

The authors declare no conflict of interest.

\section{Reerences}

1. WALAN P., DAVIDSSON S., JOHANSSON S., HÖÖK M. Phosphate rock production and depletion: Regional disaggregated modeling and global implications. Resour. Conserv. Recy. 93, 178, 2014

2. GEISSLER B., MEW M.C., STEINER G. Phosphate supply security for importing countries: Developments and the current situation. Sci. Total. Environ. 677, 511, 2019.

3. FAYIGA A.O., NWOKE O.C. Phosphate rock: origin, importance, environmental impacts, and future roles. Environ. Rev. 24(4), 403, 2016.

4. LIU X., SHENG H., JIANG S.Y., YUAN Z.W., ZHANG C.S., ELSER J.J. Intensification of phosphorus cycling in China since the 1600s. P. Natl. Acad. Sci. U. S. A. 113 (10), 2609, 2016.

5. MAAVARA T., PARSONS C.T., RIDENOUR C., STOJANOVIC S., DÜRR H.H., POWLEY H.R., VAN
CAPPELLEN P. Global phosphorus retention by river damming. P. Natl. Acad. Sci. U.S.A. 112 (51), 15603, 2015.

6. ZAK D., KRONVANG B., CARSTENSEN M.V., HOFFMANN C.C., KJELDGAARD A., LARSEN S.E., AUDET J., EGEMOSE S., JORGENSEN C.A., FEUERBACH P., GERTZ F., JENSEN H.S. Nitrogen and phosphorus removal from agricultural runoff in integrated buffer zones. Environ. Sci. Technol. 52 (11), 6508, 2018.

7. CORDELL D. The story of Phosphorus: Sustainability implications of global phosphorus scarcity for food security. Doctoral Thesis. Collaborative Ph.D. between the Institute for Sustainable Futures, University of Technology, Sydney (UTS) \& Department of Thematic Studies-Water and Environmental, Linköping University, Sweden. No. 509. Linköping University Press, Linking. 2010.

8. CORDELL D., NESET T.S.S. Phosphorus vulnerability: a qualitative framework for assessing the vulnerability of national and regional food systems to the multidimensional stressors of phosphorus scarcity. Global. Environ. Chang. 24, 108, 2014.

9. MA L., VELTHOF G.L., WANG F.H., QIN W., ZHANG W.F., LIU Z., ZHANG Y., WEI J., LESSCHEN J.P., MA W.Q., OENEMA O., ZHANG F.S. Nitrogen and phosphorus use efficiencies and losses in the food chain in China at regional scales in 1980 and 2005. Sci. Total. Environ. 434, 51, 2012.

10. BECHMANN M.E., BERGE D., EGGESTAD H.O., VANDSEMB S.M. Phosphorus transfer from agricultural areas and its impact on the eutrophication of lakes-two long-term integrated studies from Norway. J. Hydrol. 304 (1), 238, 2005.

11. EASTMAN M., GOLLAMUDI A., STÄMPFLI N., MADRAMOOTOO C.A., SARANGI A. Comparative evaluation of phosphorus losses from subsurface and naturally drained agricultural fields in the Pike River watershed of Quebec, Canada. Agr. Water. Manage. 97 (5), 596, 2010.

12. LEONE A., RIPA M.N., BOCCIA L., LO PORTO A. Phosphorus export from agricultural land: a simple approach. Biosystems Engineering. 101 (2), 270, 2008.

13. BAST B.L., MULLEN R., O'HALLORAN I., WARNCKE D., BRUULSEMA T. Phosphorus balance trends on agricultural soils of the Lake Erie Drainage Basin. Better Crops. 93 (1), 6, 2009.

14. CHEN D.J., LU J., SHEN Y.N., DAHLGREN R.A., JIN S.Q. Estimation of critical nutrient amounts based on input-output analysis in an agriculture watershed of eastern China. Agr. Ecostst. Environ. 134, 159, 2009.

15. HERZOG F., PRASUHN V., SPIESS E., RICHNER W. Environmental cross-compliance mitigates nitrogen and phosphorus pollution from Swiss agriculture. Environ. Sci. Policy. 11 (7), 655, 2008.

16. BRUNNER P., RECHBERGER H. Practical handbook of material flow analysis. CRC Press. 2003.

17. YUAN Z.W., JIANG S.Y., SHENG H., LIU X., HUA H., LIU X.W., ZHANG Y. Human perturbation of the global phosphorus cycle: changes and consequences. Environ. Sci. Technol. 52 (5), 2438, 2018.

18. WANG M.R., MA L., STROKAL M., MA W.Q., LIU X.J., KROEZE C. Hotspots for nitrogen and phosphorus losses from food production in China: A County-Scale Analysis. Environ. Sci. Technol. 52 (10), 5782, 2018.

19. LIU X., SHENG H., JIANG S.Y., YUAN Z.W., ZHANG C.S., ELSER J.J. Intensification of phosphorous cycling in China since the 1600s. P. Natl. Acad. Sci. USA. 113 (10), 2609, 2016. 
20. JIANG S.Y., YUAN Z.W. Temporal variation of phosphorus cycling and sustainable management in Chaohu lake Watershed. Environ. Sci. Technol. 49 (24), 13973, 2015

21. YUAN Z.W., WU H.J., HE X.F., LIU X. A bottom-up model for quantifying anthropogenic phosphorus cycles in watershed. J. Clean. Prod. 84, 502, 2014.

22. FIRMANSYAH I., SPILLER M., DE RUIJTER F.J., CARSJENS G.J., ZEEMAN G. Assessment of nitrogen and phosphorus flows in agricultural and urban systems in a small island under limited data availability. Sci. Total. Environ. 574, 1521, 2016.

23. WU H.J., YUAN Z.W., ZHANG Y.L., GAO L.M., LIU S.M. Life-cycle phosphorus use-efficiency of the farming system in Anhui Province, Central China. J. Clean. Prod. 83, 1, 2014.

24. LIN T., WANG J., BAI X.M., ZHANG G.Q., LI X.H., GE R.B., YE H. Quantifying and managing food-sourced nutrient metabolism in Chinese cities. Environment. International. 94, 388, 2016.

25. WU H.J., ZHANG Y.L., YUAN Z.W., GAO L.M. Phosphorus flow management of cropping system in Huainan, China, 1990-2012. J. Clean. Prod. 112, 39, 2016.

26. WU H.J., YUAN Z.W., GAO L.M., ZHANG L., ZHANG Y.L. Life-cycle phosphorus management of the crop production-consumption system in China, 1980-2012. Sci. Total. Environ. 502, 706, 2015.

27. WU H.J., YUAN Z.W., ZHANG Y.L., GAO L.M., LIU S.M. Life-cycle phosphorus use-efficiency of the farming system in Anhui Province, Central China. J. Clean. Prod. 83, 1, 2014.

28. MUGANDANI R., MAFONGOYA P. Behaviour of smallholder farmers towards adoption of Conservation Agriculture in Zimbabwe. Soil. Use. Manage. DOI: 10.1111/sum.12528, 2019.

29. LIU H.B., LUO X.J. Understanding farmers' perceptions and behaviors towards farmland quality change in Northeast China: A structural equation modeling approach. Sustainability. 10, 3345, 2018.

30. WILSON R.S., SCHLEA D.A., BOLES C.M.W., REDDER T.M. Using models of farmer behavior to inform eutrophication policy in the Great Lakes. Water. Res. 139, $38,2018$.

31. METSON G.S., IWANIEC D.M., BAKER L.A., BENNETT E.M., CHILDERS D.L., CORDELL D., GRIMM N.B., MORGAN GROVE J., NIDZGORSKI D.A., WHITE S. Urban phosphorus sustainability - Systemically incorporating social, ecological, and technological factors into phosphorus flow analysis. Environ. Sci .Policy. 47, 1, 2015.

32. WANG M.R., MA L., STROKAL M., CHU Y.N., KROEZE C. Exploring nutrient management options to increase nitrogen and phosphorus use efficiencies in food production of China. Agr. Syst. 163, 58, 2018.

33. ZHAO Z.Q., QIN W., BAI Z.H., MA L. Agricultural nitrogen and phosphorus emissions to water and their mitigation options in the Haihe Basin, China. Agr. Water. Manage. 212, 262-, 2019.

34. SUN X.H., CHEN C.L., WANG G.S., XIONG X.X., GAO P., ZHAO M., TANG Y. The prediction of phosphate rock demand in China. Acta Geoscientica Sinica. 36 (2), 213, 2015 [In Chinese].

35. MA W.Q., MA L., LI J.H., WANG F.H., SISÁK I., ZHANG F.S. Phosphorus flows and use efficiencies in production and consumption of wheat, rice, and maize in China. Chemosphere. 84 (6), 814, 2011.
36. STROKAL M., MA L., BAI Z., LUAN S., KROEZE C., OENEMA O., VELTHOF G., ZHANG F. Alarming nutrient pollution of Chinese rivers as a result of agricultural transitions. Environ. Res. Lett. 11 (2), 024, 2016.

37. DAXINI A., O'DONOGHUE C., RYAN M., BUCKLEY C., BARNES A.P., DALY K. Which factors influence farmers' intentions to adopt nutrient management planning? J. Environ. Manage. 224, 350, 2018.

38. Statistics Bureau of Anhui Province (SBAP). Anhui Statistical Yearbook. Beijing: China Statistical Press; 2016 [In Chinese].

39. JIANG Z.H., ZHONG Y.M., YANG J.P., WU Y.X.Y., LI H., ZHENG L. Effect of nitrogen fertilizer rates on carbon footprint and ecosystem service of carbon sequestration in rice production. Sci. Total. Enviro. 670, 210, 2019.

40. ZHANG Y., CHENG L., TOLONEN K.E., YIN H.B., GAO J.F., ZHANG Z.M., LI K.Y., CAI Y.J. Substrate degradation and nutrient enrichment structuring macroinvertebrate assemblages in agriculturally dominated Lake Chaohu Basins, China. Sci. Total. Environ. 627, 57, 2018.

41. MCFADDEN D. The revealed preferences of a government bureaucracy: empirical evidence. Bell Journal of Economics. 7, 55, 1976.

42. KOLLÁR B. Credit value at risk and options of its measurement. $2^{\text {nd }}$ International Conference on Economics and Social Science (ICESS 2014), Information Engineering Research Institute, Advances in Education Research. 61, 143, 2014.

43. Greene. Econometric Analysis, fifth ed. 2003; PrenticeHall Press, New York

44. LI S.S., YUAN Z.W., BI J., WU H.J., LIU H. Phosphorus flow analysis of civil food production and consumption system. Environmental Science. 32 (2), 603, 2011 [In Chinese].

45. WU H.J., YUAN Z.W., ZHANG L., BI J. Eutrophication mitigation strategies: perspectives from the quantification of phosphorus flows in socioeconomic system at county level. J. Clean. Prod. 23 (1), 122, 2012.

46. WU H.J., YUAN Z.W., GAO L.M., LIU S.M. Data uncertainties in anthropogenic phosphorus flow analysis of lake watershed. J. Clean. Prod. 69, 74, 2014.

47. YUAN Z.W., LIU X., WU H.J., ZHANG L., BI J. Anthropogenic phosphorus flow analysis of Lujiang County, Anhui Province, Central China. Ecological Modeling. 222, 1534, 2011.

48. YUAN Z.W., SHI J.K., WU H.J., ZHANG L., BI J. Understanding the anthropogenic phosphorus pathway with substance flow analysis at the city level. J. Environ. Manage. 92, 2021, 2011.

49. YUAN Z.W., SUN L., BI J., WU H.J., ZHANG L. Phosphorus flow analysis of the socioeconomic ecosystem of Shucheng County, China. Ecol. Environ. 434, 51, 2012.

50. VILLALBA G., LIU Y., SCHRODER H., AYRES R.U. Global phosphorus flows in the industrial economy from a production perspective. J. Ind. Ecol. 12 (4), 557, 2008.

51. SATTLER C., NAGEL U.J. Factors affecting farmers' acceptance of conservation measures-A case study from north-eastern Germany. Land Use Policy. 27, 70, 2010.

52. DE BOLLE S., DE NEVE S., HOFMAN G. Rapid redistribution of $\mathrm{P}$ to deeper soil layers in $\mathrm{P}$ saturated acid sandy soils. Soil Use Manage. 29, 76, 2013.

53. MOCKLER E.M., DEAKIN J., ARCHBOLD M., GILL L., DALY D., BRUEN M. Sources of nitrogen and phosphorus 
emissions to Irish rivers and coastal waters: Estimates from a nutrient load apportionment framework. Sci. Total Environ. 601-602, 326, 2017.

54. ROY B.B., CHOWDHURY R.B., BAROI A.R., RAHMAN S., POWERS S.M., MILNE N., SUJAUDDIN M. Unravelling the anthropogenic pathways of phosphorus in the food production and consumption system of Bangladesh through the lens of substance flow analysis. J. Ind. Ecol. DOI: 10.1111/jiec.12935, 2019.

55. METSON G., AGGARWAL R., CHILDERS D.L. Efficiency through proximity. J. Ind. Ecol. 16, 914, 2012.

56. NANDA M., CORDELL D., KANSAL A. Assessing national vulnerability to phosphorus scarcity to build food system resilience: The case of India. J. Environ. Manage. 240, 511, 2019

57. HAN Y., LI X., NAN Z. Net anthropogenic phosphorus accumulation in the Beijing metropolitan region. Ecosystems. 14, 445, 2011.

58. Dessart F.J., Barreiro-Hurle J., van Bavel R. Behavioural factors affecting the adoption of sustainable farming practices: a policy-oriented review. Eur. Rev. Agric. Econ. 46 (3), 417, 2019.

59. HUA L.L., LIU J., ZHAI L.M., XI B., ZHANG F.L., WANG H.Y., LIU H.B., CHEN A.Q., FU B. Risks of phosphorus runoff losses from five Chinese paddy soils under conventional management practices. Agr. Ecosyst. Environ. 245, 112, 2017.

60. KIMENGICH B.K., TAKEUCHI J., GOTO K., FUJIHARA M. Temporal and spatial change in phosphatephosphorus concentration and modeling with land-use variation in Sengari reservoir basin, Japan. Paddy. Water. Environ. 17, 131-, 2019.

61. LI Y., YEN H., LEI Q.L., QIU W.W., LUO J.F., LINDSEY S., QIN L.H., ZHAI L.M., WANG H.Y., WU S.X., LI W.C., HU W.L., LI H.Z., LIU H.B. Impact of human activities on phosphorus flows on an early eutrophic plateau: A case study in Southwest China. Sci. Total. Environ. 714, 136851, 2020.

62. QIAO F.B. Increasing wage, mechanization, and agriculture production in China. China Economic Review. 46, 249-260, 2017.

63. MOA (the Ministry of Agriculture of China). The mechanization rate of farming, breeding, and harvesting has broken through $60 \%$ in 2014. http://www.moa.gov. cn/ztzl/qgnygzh/pd2014/201412/t20141215 4295281.htm. 2014.

64. PARK A.G., MCDONALD A.J., DEVKOTA M., DAVIS A.S. Increasing yield stability and input efficiencies with cost-effective mechanization in Nepal. Field. Crop. Res. 228, 93, 2018.

65. METSON G., HALE R., IWANIEC D., COOK E., CORMAN J., GALLETTI C., CHILDERS D. Phosphorus in Phoenix: a budget and spatial approach representation of phosphorus in an urban ecosystem. Ecol. Appl. 22, 705, 2012.

66. BROCH S.W., VEDEL S.E. Using choice experiments to investigate the policy relevance of heterogeneity in farmer agri-environmental contract preferences. Environ. Resour. Econ. 51 (4), 561, 2011

67. SCHULZ N., BREUSTEDT G., LATACZ-LOHMANN U. Assessing farmers' willingness to accept "greening": Insights from a discrete choice experiment in Germany. J. Agric. Econ. 65 (1), 26, 2014.

68. ZHANG X.B., YANG J., THOMAS R. Mechanization outsourcing clusters and division of labor in Chinese agriculture. China Economic Review. 43, 184, 2017.
69. LI J., RODRIGUEZ D., TANG X.Y. Effects of land lease policy on changes in land use, mechanization and agricultural pollution. Land Use Policy. 64, 405, 2017.

70. WANG X.B., YAMAUCHI F., OTSUKA K., HUANG J.K. Wage growth, landholding and mechanization in Chinese agriculture. World Development, 86, 30, 2016.

71. MOA (the Ministry of Agriculture of China). The transfer proportion of cultivated land in China has exceeded one third. China Agri-Production News, 45, 1, 2016 [In Chinese].

72. FAN L.C., YUAN Y.M., YING Z.C., LAM S.K., LIU L., ZHANG X.C., LIU H.B., GU B.J. Decreasing farm number benefits the mitigation of agricultural non-point source pollution in China. Environ. Sci. Pollut. R. 26, 464, 2019.

73. REN C.C., LIU S., VAN GRINSVEN H., REIS S., JIN S.Q., LIU H.B., GU B.J. The impact of farm size on agricultural sustainability. J. Clean. Prod. 220, 357, 2019.

74. MACINTOSH K.A., CHIN J., JACOBS B., CORDELL D., MADOWELL R.W., BUTLER P., HAYGARTH P.M., WILLIAMS P., QUINN J.P., O'FLAHERTY V., MCGRATH J.W. Transforming phosphorus use on the island of Ireland: A model for a sustainable system. Sci. Total. Environ. 656, 852, 2019.

75. SHARPLEY A.N. Managing agricultural phosphorus to minimize water quality impacts. Sci. Agric. 73, 1, 2016.

76. ZHANG F.S. The innovation and application of integrated nutrient resource management technology to harmonize crop production and environment protection in China. Beijing: China Agricultural University Press. 2009 [In Chinese].

77. JORDAN-MEILLE L., RUBÆK G.H., EHLERT P.A.I., GENOT V., HOFMAN G., GOULDING K., RECKNAGEL J., PROVOLO G., BARRACLOUGH P. An overview of fertilizer-P recommendations in Europe: soil testing, calibration, and fertilizer recommendations. Soil Use Manag. 28, 419, 2012.

78. ZHU J., LI M., WHELAN M. Phosphorus activators contribute to legacy phosphorus availability in agricultural soils: a review. Sci. Total Environ. 612, 522, 2018.

79. HANIEF A., LAURSEN A.E. Meeting updated phosphorus reduction goals by applying best management practices in the Grand River watershed, southern Ontario. Ecol. Eng. 130, 169, 2019.

80. MALMAEUS J.M., KARLSSON O.M. Estimating costs and potentials of different methods to reduce the Swedish phosphorus load from agriculture to surface water. Sci. Total. Environ. 408, 473, 2010.

81. MANSCHADI A.M., KAUL H.P., VOLLMANN J., EITZINGER J., WENZEL W. Developing phosphorusefficient crop varieties-An interdisciplinary research framework. Field. Crop. Res. 162, 87, 2014.

82. LYNCH J.P. Root phenes for enhanced soil exploration and phosphorus acquisition: tools for future crops. Plant. Physiol. 156, 1041, 2011.

83. SMITH D.R., OWENS P.R., LEYTEM A.B., WARNEMUENDE E.A. Nutrient losses from manure and fertilizer applications as impacted by time to first runoff event. Environ. Pollut. 147, 131, 2007.

84. BRENNAN R.B., HEALY M.G. The impact of chemical amendment of dairy cattle slurry before land application on soil phosphorus dynamics. Commun. Soil. Sci. Plan. 45, 2215-2233, 2014.

85. BUDA A.R., CHURCH C., KLEINMAN P.J.A., SAPORITO L.S., MOYER B.G., TAO L. Using rare 
earth elements to control phosphorus and track manure in runoff. J. Environ. Qual. 39, 1028, 2010.

86. SCHRÖDER J.J., SMIT A.L., CORDELL D., ROSEMARIN A. Improved phosphorus use efficiency in agriculture - A key requirement for its sustainable use. Chemosphere. 84, 822, 2011.

87. VAN DER KOOIJ S., VAN VLIET B.J.M., STOMPH T.J., SUTTON N.B., ANTEN N.P.R., HOFFLAND E. Phosphorus recovered from human excreta: A socioecological-technical approach to phosphorus recycling. Resour. Conserv. Recy. 157, 104744, 2020.

88. MA L., GUO J.H., VELTHOF G.L., LI Y.M., CHEN Q., MA W.Q., OENEMA O., ZHANG F.S. Impacts of urban expansion on nitrogen and phosphorus flows in the food system of Beijing from 1978 to 2008. Global. Environ. Change. 28, 192, 2014.

89. State Council (China). Central Document No.1: State Council's opinions on the key work of "agriculture, rural areas and farmers" to ensure realizing a well-off society as scheduled. http://www.gov.cn/zhengce/2020-02/05/ content_5474884.htm, 2020 [In Chinese].
90. CHAND R. Doubling farmer's income: Rationale, strategy, prospects and action plan (Policy Paper No. 1/2017). NITI Ayog, Government of India, New Delhi, India. 2017.

91. EPPER C.A., PAUL B., BURRA D., PHENGSAVANH P., RITZEMA R., SYFONGXAY C., GROOT J.C.J., SIX J., FROSSARD E., OBERSON A., DOUXCHAMPS S. Nutrient flows and intensification options for smallholder farmers of the Lao uplands. Agr. Syst. 177, 102694, 2020.

92. SENDHIL R., RAMASUNDARAM P., BALAJI S.J. Transforming Indian agriculture: is doubling farmers' income by 2022 in the realm of reality? Curr. Sci. 113, 848, 2017.

93. DINANI O.P., TYAGI P.K., GIRI A.K., POPAT D.S. Role of livestock in doubling the farmers' income - national perspective and the way forward. Int. J. Sci. Environ. 7, 496, 2018.

94. SCHOUMANS O.F., BOURAOUI F., KABBE C., OENEMA O., VAN DIJK K.C. Phosphorus management in Europe in a changing world. Ambio. 44, 180, 2015. 
